ENTREPRENEURSHIP AND SUSTAINABILITY ISSUES

ISSN 2345-0282 (online) http://jssidoi.org/jesi/ 2020 Volume 8 Number 1 (September)

http://doi.org/10.9770/jesi.2020.8.1(82)

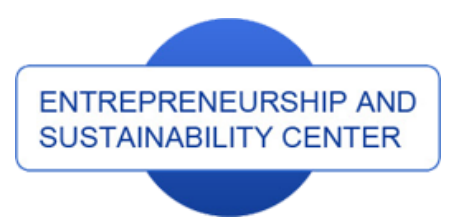

Publisher

http://jssidoi.org/esc/home

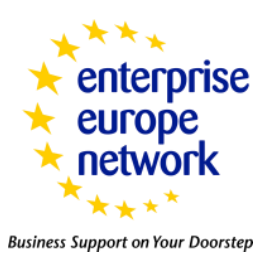

\title{
FINANCIAL-CREDIT AND INNOVATIVE ECONOMIC SECTORS: EVALUATION OF MACROECONOMIC EFFECTS OF REGULATION AND INTERACTION SECTORS*
}

\author{
Aibota Rakhmetova ${ }^{1}$, Gaukhar Kalkabayeva ${ }^{2}$, Anar Kurmanalina ${ }^{3}$, Zhanar Gusmanova ${ }^{4}$, \\ Gulzira Serikova ${ }^{5}$, Baglan Aimurzina ${ }^{6}$
}

\author{
1,2,3,4,5 Karaganda Economic University of Kazpotrebsoyuz, Akademicheskaya 9 street, Karaganda, Kazakhstan \\ ${ }^{6}$ Kazakh University of Economics, Finance and International Trade, Nur-Sultan, Kazakhstan \\ E-mails:1aibota@mail.ru ; ${ }^{2 a i s a n a t a z h b a e v a @ m a i l . r u}$; ${ }^{3}$ anar68@mail.ru ; ${ }^{4}$ gusmanova78@mail.ru ; \\ serikovagul@mail.ru; ${ }^{5}$ aimurzina@mail.ru
}

Received 15 March 2020; accepted 8 August 2020; published 30 September 2020

\begin{abstract}
In the article, the authors examine contemporary problems of the divergence of the interests of financial and credit institutions and enterprises operating in the innovation sector. Based on the study of theoretical and methodological approaches to the interaction of subjects of financial and innovative sectors of the economy, the authors obtained the results of economic-mathematical modeling on the effect of interaction between sectors on economic growth and assess the role of regulators in this process. The obtained results are interpreted through the prism of the experience of economically developed countries, which reached the greatest degree of synergy between the financial and innovative sectors of the economy. Conclusions are drawn regarding the need to develop preventive measures to eliminate the undesirable effects, including on the basis of the adaptation of best world experience.
\end{abstract}

Keywords: financial sector; innovation sector; interaction; economic growth; synergy; macroeconomic effects; institutional infrastructure; regulation

Reference to this paper should be made as follows: Rakhmetova, A., Kalkabayeva, G., Kurmanalina, A., Gusmanova, Zh., Serikova, G., Aimurzina, B. 2020. Financial-credit and innovative economic sectors: evaluation of macroeconomic effects of regulation and interaction sectors. Entrepreneurship and Sustainability Issues, 8(1), 1224-1237. http://doi.org/10.9770/jesi.2020.8.1(82)

JEL Classifications: E22, E31, E44

\footnotetext{
* The article was prepared based on the results of an intermediate stage of research "Development of a systematic regulation mechanism for financial and credit organizations to support the innovation sector in the context of sustainable macroeconomic effects", carried out under grant funding of the Ministry of Education and Science of the Republic of Kazakhstan Grant Agreement Number 0118 PK01143
} 


\section{ENTREPRENEURSHIP AND SUSTAINABILITY ISSUES}

ISSN 2345-0282 (online) http://jssidoi.org/jesi/

2020 Volume 8 Number 1 (September)

http://doi.org/10.9770/jesi.2020.8.1(82)

\section{Introduction}

In the current conditions of development of Kazakhstan, characterized by a progressive movement towards the development of the processing industry, one of the urgent directions for the development of interaction between the financial and real sectors of the economy is an innovative form of interaction, which in terms of its development is significantly inferior to investment, but in terms of demand from real (innovative) sectors of the economy and from the standpoint of the need to address key tasks of socio - economic power, significantly surpasses it.

The basis of the organization of this form of interaction is venture financing related to the commercialization of research results in high technology, high-tech areas where the results are not guaranteed and the risks are high (Nakipova, Akhmetova, Kamenova, 2013). It is noteworthy that in most European countries, risk capital has received significant development with the support of the financial sector and the state, which began to fulfill simultaneously the role of co-financier, organizer, source of information and customer. Despite the complexity of implementing this form of interaction (venture business is highly risky, and financial and credit organizations cannot risk borrowed funds), the prospects for the development of this form of interaction between financial and innovative sectors of the economy associated with the transition of Kazakhstan to an innovative development path in order to implement a structural economic restructuring (Rakhmetova, Kalkabayeva, Iskakova, Kurmanalina, Turmakhanbetova, 2019)

At the initial stage of this path, it is proposed to develop this form of interaction through loans from large entities of the banking sector with state participation, which can finance large-scale risk projects. Countries with a high share of the banking sector in the economy (in terms of the ratio of loans to GDP) also include Spain - 207.1\%, the UK - 171.5\%, France - 147.9\% and Germany - 141.1\% (Zavadska, 2018, Dwenger, Fossen, Simmler, 2020). For example, in France back in the 80s there was a reorganization of the banking system, the essence of which was to strengthen the processes of nationalization of individual sectors of the national economy and financial and credit institutions. The basis for such a reform was the need to overcome the crisis and the need to modernize large industrial enterprises based on the intensive introduction of innovations. Thus, in accordance with the Law on Nationalization, CompagnieFinancieredeParisetdesPays - Bas, known today as Paribas and CompagnieFinancieredeSuez, were nationalized, who later became shareholders in five nationalized industrial groups. Among quasi-state institutions, one can distinguish CreditNational activity aimed at providing loans to industries for up to 5 years, primarily to small and medium-sized businesses, the costs associated with the acquisition of equipment and construction. One of the incentive measures was the creation of the state company OSEO, whose main function was to stimulate the innovation process and increase the competitiveness of enterprises in the innovation sector by providing a guarantee of up to $90 \%$ of the amount of the requested loan and implementing joint financing with banks (Egyed, Pola, 2020). In China, the functions of financial support for the national economy were transferred to specialized state banks (Agricultural Bank, Commercial and Industrial Bank, Construction Bank and Bank of China). At the same time, the reform of the banking system in subsequent years increased the state's share in the banking sector to $61.1 \%$ of all banking assets, concentrating them in four state and three political banks. At the same time, Chinese laws impose strict restrictions on capital outflows, which is why most of the resources The banking sector is located domestically. The cost of loans for innovative enterprises remains low, therefore this source is more preferable for them than operations with securities $(\mathrm{Wu}, \mathrm{Xu}$, 2020). In Spain, a specially created network of specialized state credit institutions represented by the Mortgage Bank, Stroybank, Industrial Bank, Local Credit Bank, Foreign Economic Bank and Central Bank, along with private commercial banks, covers the entire needs of the real sector in the priority areas of navigation and fishing (Shchenin, 2010). In order to balance the redistribution of resources between priority sectors of the economy, the State Credit Institute has been established here, which gives preference to those enterprises that actively invest in 


\section{ENTREPRENEURSHIP AND SUSTAINABILITY ISSUES}

ISSN 2345-0282 (online) http://jssidoi.org/jesi/

2020 Volume 8 Number 1 (September)

http://doi.org/10.9770/jesi.2020.8.1(82)

research and development $(\mathrm{R} \& \mathrm{D})$, use resource-saving technologies in their production, expand exports, and contribute to protection environment (Hombert, Matray, 2019).

In order to maintain economic growth, the government of Japan in the 90s decided to nationalize two long-term lending banks LongTermCreditBank and NipponCreditBank and to merge two development banks with state financial funds: Development Bank of Japan with Hokkaido-Tohoku Development Finance Public Corporation and Export - Import Bank of Japan with Overseas Fundation Economic, having agreed upon financing schemes mutually acceptable for the state and sectors (Shioji, 2019). At the beginning of the 20th century, these institutions made a significant contribution to the development of the Japanese economy by providing long-term loans to enterprises belonging to the most priority sectors of the real sector. At present, including being again transferred to private hands; they are engaged in lending to enterprises of high-tech and high-tech industries. In the Russian Federation, large banks with state participation (OJSC Sberbank of Russia, OJSC Russian Agricultural Bank, OJSC Bank Vozrozhdenie, OJSC Prosvyazbank) use products oriented to the innovation sector (Polyakova, 2012). So, the Development Bank (Vnesheconombank) has launched the Financing for Innovation and Modernization program, under which the partner banks of RBD will receive financial support from the latter for the implementation of innovative projects in the SME sector in the amount of up to 150 million rubles for a period of less than 7 years at a rate of $2 / 3$ of the Bank of Russia refinancing rate. It is assumed that the share of loans in innovative projects should be $20 \%$ of the total investment in a particular industry (Shmeleva, 2017).

Kazakhstan's experience in using venture financing is so far limited to the activities of specialized venture funds, including those with participation in the capital of the state and large banks. There are examples of international practice of the participation of banks of Kazakhstan and Russia in venture financing of enterprises in the real sector on the basis of signing an agreement between OJSC RUSNANO, JSC Kazyna Capital Management, VTB Capital Group and I2BFHoldings on the creation of a Russian-Kazakhstan venture fund (target size 100 million US dollars) to support projects aimed at the introduction of nanotechnology and the use of nanotechnology products in various sectors of the economy of the Republic of Kazakhstan and the Russian Federation (Official site of RUSNANO) as well as the Eurasian Development Bank (EDB), which finances projects with the introduction of innovative technologies (construction of a SukhoiSuperjet passenger aircraft, a plant for the production of polycrystalline silicon "Usolye Sibirsky Silicone", a project of Kazfrac LLP for gas utilization at the Kenlyk field, etc.) (Finogenov, 2012).

In countries where strategic documents aimed at the development of innovative activity have been adopted and are being implemented (State program of industrial and innovative development of the RK), and the financial system model is close to the European one, the so-called hybrid varieties of this form of interaction will predominantly develop in the medium term, involving joint participation in financing the innovation sector of banks, the state and institutional investors (Strategy of innovative development of the RF). The role of the state in expanding this form of interaction is determined by the need to use instruments of subsidizing, insurance and guarantee, without which it is impossible to achieve success in this area.

\section{Methodological approach}

The methodological basis of the study was the work of domestic and foreign scientists who are devoted to fundamental research in the development of the theory: systems, banking, credit, interaction, asymmetry, institutionalism and state regulation of the economy. In particular, the methodology of the presented study is based on the works of I.V. Blauberg, V.N. Sadovsky, E.G. Yudin (Blauberg, 1969), who considered the object of study as a complex of interconnected and interacting elements, as well as a combination of entities and relationships. Using the methodology of a systemic reproductive approach in the study allows us to show the process of interaction between subjects of the financial and innovative sectors of the economy as a set of elements 


\section{ENTREPRENEURSHIP AND SUSTAINABILITY ISSUES}

ISSN 2345-0282 (online) http://jssidoi.org/jesi/

2020 Volume 8 Number 1 (September)

http://doi.org/10.9770/jesi.2020.8.1(82)

of the economic system functioning and interconnecting each other (the relationship between the whole and its parts) and confirm the thesis that the nature, quality and direction of interaction between subjects of sectors largely determine the sustainable development of the modern economic system (the impact of large macroeconomic FIR trends and its development on the economy).

Moreover, the connection between the two methodological paradigms is due to the fact that it is the institutions that determine not only the course, but also the course of the processes taking place in the economy, ensure the integration of the social whole, smooth out the conflicting interests of many system elements (financial and real sectors, as well as the state), and, ultimately, determine the stability of the functioning of both the elements themselves and the economic system formed by them.

Along with the methodology of the systematic approach, the study also relies on the development of the founders of the theory of institutionalism T. Veblen (Veblen, 1984), J. Schumpeter (Schumpeter, 1982), D. North (North, 1997), the institutional theory of R. Coase (Coase,1993) and representatives of the Russian school of institutionalism G. B. Kleiner, V.M. Polterovich (Polterovich, 2016), whose attention, when conducting research, is focused on the analysis of conditions that determine the viability of mechanisms for reconciling the interests of fully functioning and developing economic entities and the interests of the state and society as a whole.

However, for all the depth of research and the results obtained by these authors, questions remain underexplored, revealing the influence of a modified set of macroeconomic factors of the external and internal environment on the process of interaction between the banking and real sectors of the economy in the new economic conditions, the search for ways to improve the quality and stability of the interaction trajectory of sectors, productivity state participation in conditions of growing crisis, increasing the role of financial and credit organizations in the development of the innovation sector and others (Rozmainsky, 2017).

Issues of institutional modernization of the financial system are reflected in the works: G.N. Beloglazova (Beloglazova, 2011), G.A. Tosunyan (Tosunyan, 2018), I. Tselishchev (Tselishchev, 2019), G.L. Avagyan (Avagyan, 2012), T.N. Zverkova (Zverkova, 2018), and others. The obtained results of these studies cover topical issues in the field of interaction between subjects of the financial and real (including innovative) sectors of the economy in modern conditions are fragmented and do not take into account the relationship between the elements of a complex systemic process of interaction between the subjects of these sectors.

\section{Materials and methods}

When selecting data for assessing the first group of dependencies of GDP growth rates on innovation and investment activities, the difference in the assessment of innovations by different groups of countries was taken

into account. For example, in Kazakhstan, generally accepted indicators for assessing innovation in statistical reporting are such quantitative indicators as the number and share of enterprises implementing technological innovations, the share of $\mathrm{R} \& \mathrm{D}$ expenditures in their total volume, etc. The practice of foreign countries indicates that these indicators do not reflect the final result of innovation, so they use as a key indicator - the share of hightech products in total exports, which would 1 was taken as the basis for evaluating innovation.

A wide range of indicators of a temporal and spatial nature was used in the work, given that the process of interaction between sectors is influenced by a set of interrelated micro-, meso- and macroeconomic factors, and the subjects are distinguished from each other by the specifics of their activities and institutional environment. As a measure of institutional characteristics, one of four main methods was chosen - based on macroeconomic indicators - characterizing the degree of development of the relationship between the subjects of the studied sectors. The logic of structuring macroeconomic parameters is based on key factors of economic development that are directly related to the process of interaction between the financial and innovative sectors of the economy. 
In the research process, general scientific, special methods and such methods of scientific knowledge were used as statistical, graphic, expert, comparative and modeling.

\section{Qualitative and Quantitative Research}

For a comparative analysis, we selected countries that occupy high positions in the ranking of the Global Innovation Index: Sweden - 2nd place, the Netherlands - 3rd place, Singapore - 9th place and for comparison Kazakhstan, which takes not a high 78th place in the rating. As can be seen from the data in Table 1, the largest value of the export of high-tech products among the analyzed group of countries for 2016 belongs to Singapore (126.3 billion US dollars), although it has a slight negative dynamics over the past 4 years. the studied period, the volume of exports of high-tech products in Kazakhstan increased by 2.1 times, while in Singapore - 1.7, the Netherlands - 1.2, and in Sweden - on the contrary, has a tendency to decrease by 1.3 billion dollars. USA.

Table 1. GDP and high-tech products by country (in billion US dollars)

\begin{tabular}{|c|c|c|c|c|c|c|c|c|}
\hline \multirow[b]{2}{*}{ Years } & \multicolumn{2}{|c|}{ Sweden } & \multicolumn{2}{|c|}{ Netherlands } & \multicolumn{2}{|c|}{ Singapore } & \multicolumn{2}{|c|}{ Kazakhstan } \\
\hline & $\begin{array}{c}\text { GDP } \\
\text { (billion US } \\
\text { dollars) } \\
\end{array}$ & $\begin{array}{c}\text { High- } \\
\text { technology } \\
\text { exports } \\
\text { (billion US } \\
\text { dollars) } \\
\end{array}$ & $\begin{array}{c}\text { GDP } \\
\text { (billion } \\
\text { US } \\
\text { dollars) }\end{array}$ & $\begin{array}{c}\text { High- } \\
\text { technology } \\
\text { exports } \\
\text { (billion US } \\
\text { dollars) } \\
\end{array}$ & $\begin{array}{c}\text { GDP } \\
\text { (billion } \\
\text { US } \\
\text { dollars) } \\
\end{array}$ & $\begin{array}{l}\text { High- } \\
\text { technology } \\
\text { exports } \\
\text { (billion US } \\
\text { dollars) } \\
\end{array}$ & $\begin{array}{c}\text { GDP } \\
\text { (billion } \\
\text { US } \\
\text { dollars) } \\
\end{array}$ & $\begin{array}{c}\text { High- } \\
\text { technology } \\
\text { exports } \\
\text { (billion US } \\
\text { dollars) } \\
\end{array}$ \\
\hline 2000 & 259,8 & 16,2 & 412,8 & 44,9 & 95,8 & 73,9 & 18,3 & 0,0 \\
\hline 2001 & 239,9 & 10,8 & 426,6 & 38,9 & 89,3 & 62,5 & 22,2 & 0,0 \\
\hline 2002 & 263,9 & 12,3 & 465,7 & 34,1 & 91,9 & 64,1 & 24,6 & 0,2 \\
\hline 2003 & 331,1 & 13,5 & 571,9 & 50,2 & 97,0 & 76,4 & 30,8 & 0,2 \\
\hline 2004 & 381,7 & 17,3 & 650,5 & 60,1 & 114,2 & 94,2 & 43,2 & 0,3 \\
\hline 2005 & 389,0 & 17,3 & 678,5 & 65,9 & 127,4 & 105,6 & 57,1 & 0,4 \\
\hline 2006 & 420,0 & 18,4 & 726,6 & 69,5 & 147,8 & 124,7 & 81,0 & 0,9 \\
\hline 2007 & 487,8 & 15,1 & 839,4 & 67,4 & 179,9 & 102,8 & 104,8 & 1,5 \\
\hline 2008 & 513,9 & 15,4 & 936,2 & 58,1 & 192,2 & 117,1 & 133,4 & 2,3 \\
\hline 2009 & 429,7 & 12,8 & 857,9 & 50,8 & 192,4 & 95,4 & 115,3 & 1,8 \\
\hline 2010 & 488,4 & 16,2 & 836,4 & 59,5 & 236,4 & 126,9 & 148,0 & 2,4 \\
\hline 2011 & 563,1 & 18,5 & 893,8 & 67,1 & 275,6 & 126,4 & 192,6 & 2,6 \\
\hline 2012 & 543,9 & 16,6 & 828,9 & 64,1 & 289,2 & 128,2 & 207,9 & 3,5 \\
\hline 2013 & 578,7 & 17,1 & 866,7 & 69,0 & 302,5 & 135,6 & 236,6 & 3,1 \\
\hline 2014 & 573,8 & 16,6 & 879,6 & 70,3 & 308,1 & 137,4 & 221,4 & 3,3 \\
\hline 2015 & 497,9 & 14,9 & 757,9 & 59,1 & 296,8 & 130,9 & 184,4 & 2,8 \\
\hline 2016 & 514,5 & 14,9 & 777,2 & 53,0 & 296,9 & 126,3 & 137,3 & 2,1 \\
\hline 2017 & 541,0 & 17,4 & 833,8 & 78,2 & 341,8 & 147,2 & 166,8 & 1,8 \\
\hline 2018 & 555,4 & 17,4 & 914,1 & 85,7 & 373,2 & 155,4 & 179,3 & 1,8 \\
\hline 2019 & 530,8 & 17,5 & 909,1 & 85,7 & 372,1 & 155,4 & 180,2 & 2,2 \\
\hline
\end{tabular}

Source: compiled by authors according to data from the World Bank 
ENTREPRENEURSHIP AND SUSTAINABILITY ISSUES

ISSN 2345-0282 (online) http://jssidoi.org/jesi/ 2020 Volume 8 Number 1 (September)

http://doi.org/10.9770/jesi.2020.8.1(82)
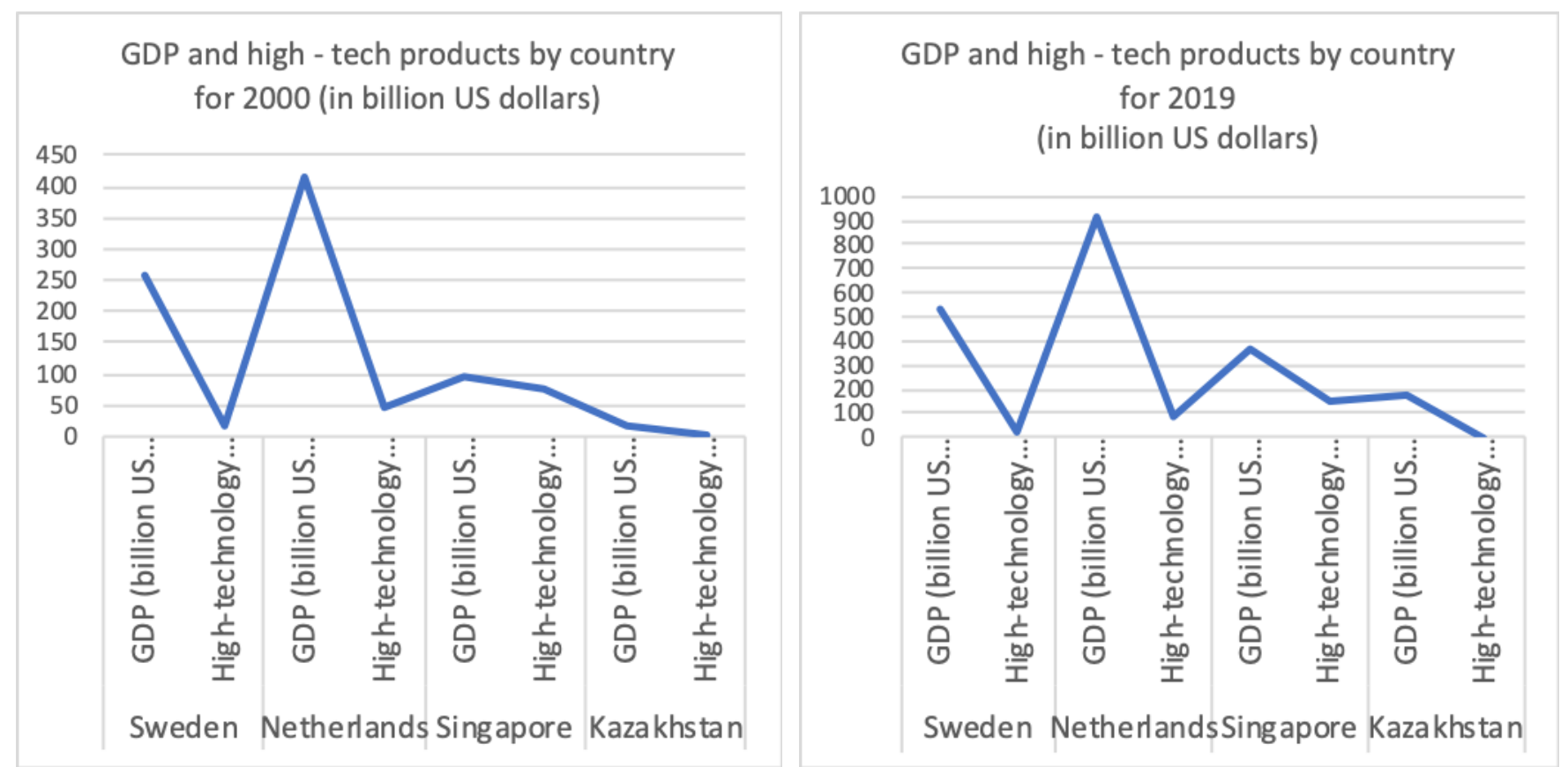

Figure 1. GDP and high-tech products by country Source: compiled by authors according to data from the World Bank

In order to assess the role of innovation in the real sector in the development of the economic system as a whole, we compared the values of the ratio of the export of high-tech products in\% to GDP. It should be noted that, according to the results of the analyzed period, the greatest contribution to the development of the economy is made by Singapore's innovations (42.54\%), which is 6 times higher than the value in the Netherlands $(6.82 \%)$, almost 15 times higher than in Sweden (2.89\%), and 28.4 times in Kazakhstan, despite the contradictory dynamics in recent years of the study period (Table 2). In our opinion, for Kazakhstan, even a relatively small, but progressive increase in the value of this indicator over the entire analyzed period is a very positive characteristic from the standpoint of implementing the strategy of innovative and industrial development.

Table 2. The share of high-tech products in $\%$ of the GDP of Sweden, the Netherlands, Singapore and Kazakhstan

\begin{tabular}{|l|l|l|l|l|}
\hline Year & Sweden & Netherlands & Singapore & Kazakhstan \\
\hline 2000 & 6,24 & 10,87 & 77,13 & 0,00 \\
\hline 2001 & 4,50 & 9,13 & 70,06 & 0,22 \\
\hline 2002 & 4,66 & 7,33 & 69,74 & 0,80 \\
\hline 2003 & 4,08 & 8,79 & 78,77 & 0,65 \\
\hline 2004 & 4,53 & 9,23 & 82,52 & 0,65 \\
\hline 2005 & 4,45 & 9,71 & 82,92 & 0,73 \\
\hline 2006 & 4,38 & 9,56 & 84,39 & 1,22 \\
\hline 2007 & 3,09 & 8,03 & 57,15 & 1,39 \\
\hline 2008 & 2,99 & 6,21 & 60,90 & 1,69 \\
\hline 2009 & 2,98 & 5,92 & 49,58 & 1,56 \\
\hline 2010 & 3,32 & 7,12 & 53,71 & \\
\hline 2011 & 3,28 & 7,51 & 45,88 & \\
\hline 2012 & 3,05 & 7,74 & 44,35 & 1,59 \\
\hline
\end{tabular}




\section{ENTREPRENEURSHIP AND SUSTAINABILITY ISSUES}

ISSN 2345-0282 (online) http://jssidoi.org/jesi/ 2020 Volume 8 Number 1 (September) http://doi.org/10.9770/jesi.2020.8.1(82)

\begin{tabular}{|l|l|l|l|l|}
\hline 2013 & 2,95 & 7,97 & 44,83 & 1,29 \\
\hline 2014 & 2,89 & 7,99 & 44,58 & 1,50 \\
\hline 2015 & 2,99 & 7,80 & 44,13 & 1,54 \\
\hline 2016 & 2,89 & 6,82 & 42,54 & 1,50 \\
\hline 2017 & 0,032 & 0,094 & 0,43 & 0,01 \\
\hline 2018 & 0,031 & 0,093 & 0,416 & 0,098 \\
\hline 2019 & 0,033 & 0,093 & 0,416 & 0,012 \\
\hline
\end{tabular}

Source: compiled by authors according to data from the World Bank

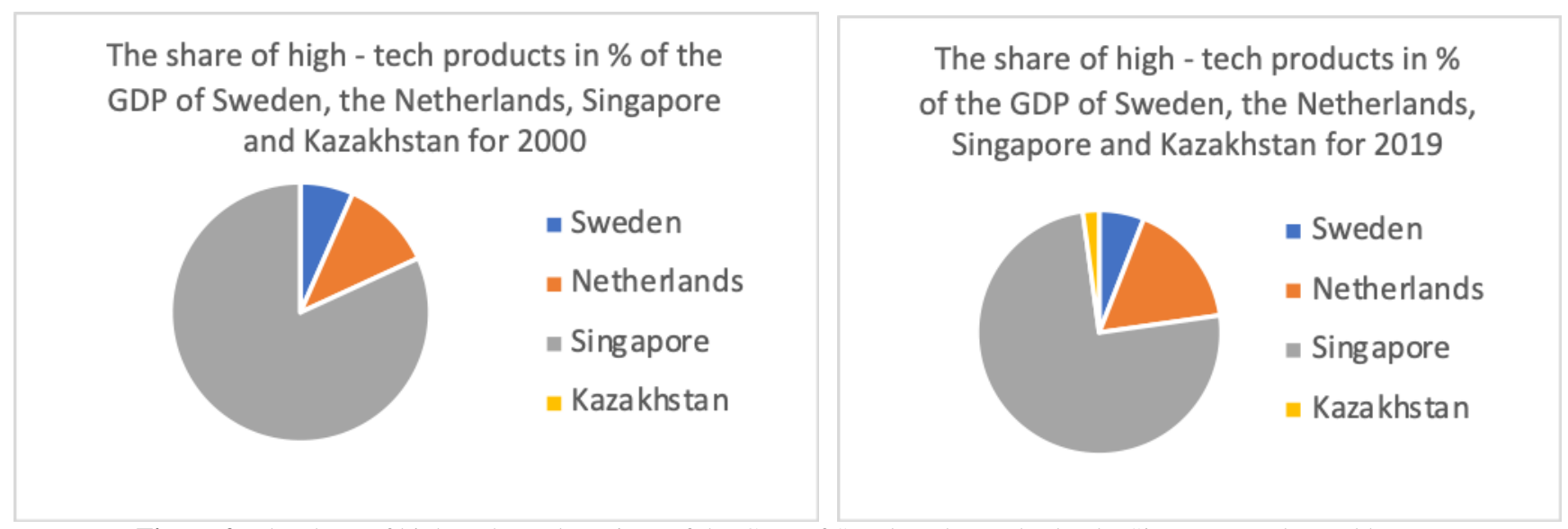

Figure 2. The share of high-tech products in $\%$ of the GDP of Sweden, the Netherlands, Singapore and Kazakhstan Source: compiled by authors according to data from the World Bank

For a more detailed and qualitative analysis of the role of innovation in economic development, we have expanded the range of factors that have the strongest influence on the quality of innovation and their dynamics. These factors included: the share of high-tech goods in the country's total industrial exports (High-technology exports, \% of manufactured exports), the share of research and development (R\&D) expenditures (\% of GDP) and the share of domestic loans related to the country's GDP (Domestic credit to private sector,\% of GDP).

The results of a comparative analysis showed negative dynamics of GDP growth rates for the entire study period: in Sweden from $4.7 \%$ to $3.2 \%$, in the Netherlands - from $4.2 \%$ to $2.2 \%$, in Singapore - from $8.9 \%$ to $2 \%$ in Kazakhstan - from $9.8 \%$ to $1.1 \%$. Such a significant slowdown in economic growth is associated with the action of factors of a predominantly globalization and integration nature. Many experts note that the lack of pronounced growth originates in the crisis of 2007-2009, after which the economies of most countries could not recover, and even those in which the innovative component is very strong, which, in the opinion of institutional scientists, can quickly end the recession and go to a confident rise. Important in this case is the effect of the growth factor of $\mathrm{R} \& \mathrm{D}$ and the availability of financial sources for both the financial and innovative sectors of the economy in order to enhance mutually beneficial cooperation between their entities.

In particular, at the end of the analyzed period, the share of high-tech products in the total industrial export in Singapore amounted to $67.4 \%$ against the background of the growth of this indicator over the entire period by 4.6\%. In Kazakhstan, rapid growth of this indicator for the entire study period by $26.8 \%$ was noted, which made it possible to reach $30.4 \%$ at the end of 2016. In Sweden and the Netherlands, despite a high position in the Global ranking of innovations, there is a similar tendency to decrease in the share of high-tech products in the total volume of industrial exports for the period 2000-2016. So, the value of this indicator in Sweden at the end of the analyzed period amounted to $14.3 \%$ (decrease by $8.5 \%$ ), in the Netherlands - $17.8 \%$ (decrease by $17.8 \%$ ), respectively. 


\section{ENTREPRENEURSHIP AND SUSTAINABILITY ISSUES}

ISSN 2345-0282 (online) http://jssidoi.org/jesi/

2020 Volume 8 Number 1 (September)

http://doi.org/10.9770/jesi.2020.8.1(82)

We are led to contradictory conclusions by the analysis of the R\&D expenditure indicator to GDP for the studied group of countries. Thus, the largest share of R\&D expenditures to GDP is observed in countries such as Sweden and Singapore, where the share of research and development expenditures ranges from $3.1 \%$ to $3.9 \%$ and $1.8 \%$ to $2.6 \%$, respectively the period 2000-2016, while the share of R\&D expenditures in Kazakhstan is negligible, and amounts to only $0.2 \%$ of GDP, without changing its value over the past 15 years.

The obtained results confirm the thesis that the growth of the R\&D expenditure indicator in modern conditions of Kazakhstan does not practically affect the results of innovative activity (only in the case of an increase in quantitative indicators). This is due to the fact that in Kazakhstan, in the context of the so-called catching up development, the prevailing experience is the purchase of finished foreign equipment and technologies that do not require a long period of their implementation (on average up to 3 years) and borrowed innovative technologies are being increasingly used, which allows to increase the share high-tech products in total industrial exports. On the contrary, the decrease in the value of a similar indicator in such highly developed countries that have a strong innovation component, such as Sweden and the Netherlands, is explained by the fact that a complete cycle of the innovation process is practiced here, which takes on average up to 10-15 years.

Of particular interest in the study of the relationship between financial and innovation sector entities and the impact of this process on economic growth are the results of the assessment of the indicator of domestic bank loans to GDP (Official site of the World Bank). According to the data in Appendix 1, the comparatively largest contribution to the development of the economy, including through lending to innovations, is made by the banks of Singapore and Sweden, where the values of the studied indicator at the end of the analyzed period amounted to $132.9 \%$ and $128.8 \%$ of GDP, respectively, against the background of a steady and progressive This indicator grew by $36.6 \%$ and $38.3 \%$, respectively, over the entire period. The Netherlands also has a high share of loans to GDP $110.4 \%$, but with insignificant negative dynamics in recent years. Kazakhstan is characterized by a relatively low share of loans to GDP - $33.4 \%$ amid growth over the period - by $22.2 \%$.

The results of a comparative analysis indicate a different degree of dependence of entities in the real sector on borrowed funds that financial and credit organizations can provide them. It should also be noted that a restrained policy of using credit resources by Kazakhstani entities of the real sector is explained by high risks that banks do not want to take and the presence of a sufficient amount of own funds from large companies that can afford the costs of implementing projects. Unfortunately, for small businesses that could most successfully use loans to implement their innovative ideas, credit resources are usually not available, primarily because of the size of interest remuneration and other conditions due to the gradual tightening of regulation on the part of financial regulator.

\subsection{Multinomial Logistic Regression}

The logistic regression model, in our opinion, is the most suitable for solving our tasks. The choice of this model (the logistic regression equation) is due to the need to determine the strength of the relationship between variables and allows us to draw conclusions about the direction and degree of mutual influence between indicators.

To identify the degree of influence of various factors on the rate of economic growth, we have built a correlationregression model. The GDP growth rate (GDP growth, annual\%) - Y was taken as an effective sign. Based on the results of an analytical study, factor signs were selected that determine, in our opinion, the change in Kazakhstan's economic growth rates:

$\mathrm{x}_{1}$ - the share of high-tech goods exports in the total volume of industrial goods exports, in \%;

$\mathrm{x}_{2}-\mathrm{R} \& \mathrm{D}$ expenditures in $\%$ of GDP;

$\mathrm{x}_{3}-$ share of domestic loans to the private sector in $\%$ of GDP.

To identify the most significant factors of them, we conducted an analysis of paired coefficients and correlation indices with an assessment of their uniqueness (significance). For this purpose, a matrix of paired correlation 
coefficients was compiled, which measures the tightness of the connection between factor and effective attributes. Selected factors were studied for the period 2000-2016. The matrix of pair wise coefficients is presented in table 3.

Table 3. Matrix of paired correlation coefficients

\begin{tabular}{|l|l|l|l|l|}
\hline & $\mathrm{Y}$ & $\mathrm{X}_{1}$ & $\mathrm{X}_{2}$ & $\mathrm{X}_{3}$ \\
\hline $\mathrm{Y}$ & 1 & & & \\
\hline $\mathrm{x}_{1}$ & 0,6123 & 1 & & \\
\hline $\mathrm{x}_{2}$ & 0,0932 & 0,2417 & 1 & \\
\hline $\mathrm{x}_{3}$ & 0,1939 & 0,3093 & 0,0049 & 1 \\
\hline
\end{tabular}

Source: compiled by authors

The studied factor $\mathrm{x} 1$ has a rather high paired coefficient with GDP growth rates. The tightness of the correlation between the trait and the factors $\mathrm{x} 2, \mathrm{x} 3$ is weak, which is confirmed by the low values of the correlation coefficients. Therefore, factor attributes $\mathrm{x} 2, \mathrm{x} 3$ can be excluded from the model.

Based on the data in Table 3, based on the results of calculating pair correlation coefficients and using the program "Information Technology of Linear Regression", the values of the variance and regression analysis indicators were obtained (Table 4 and Table 5).

Table 4. Regression statistics

\begin{tabular}{|l|l|}
\hline Multiple R & 0,782338 \\
\hline R- square & 0,612052 \\
\hline Normalized R-squared & 0,586189 \\
\hline Standard error & 2,407988 \\
\hline Observations & 17 \\
\hline \multicolumn{2}{l}{ Source: compiled by authors }
\end{tabular}

The factor variance of the productive attribute, amounting to 137.22, far exceeds the value of the residual variance of the productive attribute, equal to 5.79 (table 5).

Table 5. Analysis of variance

\begin{tabular}{|l|l|l|l|l|l|}
\hline & df & SS & MS & F & Significance F \\
\hline Regression & 1 & 137,2192 & 137,2192 & 23,66499 & 0,000206 \\
\hline Remainder & 15 & 86,97609 & 5,798406 & & \\
\hline Total & 16 & 224,1953 & & & \\
\hline \multicolumn{7}{|l|}{ Source: compiled by authors } \\
\hline
\end{tabular}

According to the results of the analysis of variance, a significant part of the variation in GDP growth depends on the impact of the studied factor. In turn, the coefficient of determination, calculated as the ratio of the factorial variance to the total variance, was 0.61 or $61 \%$ (in table 5, the coefficient of determination is presented as an Rsquare). This means that the factor included in the regression equation explains $61 \%$ of the variation in rates GDP growth, if we consider the values of indicators for the period 2000-2016.

The validity of the model is confirmed by the value of the Fisher F-test. The practical F - Fisher criterion was 23.66 and turned out to be larger than the theoretical F, which is 4.070. This means that the constructed regression model is legitimate. 
Conducted correlation and regression analysis made it possible to identify a factor that significantly affects the variation (y). The calculated regression coefficients allow a quantitative assessment of the range of changes in the rate of GDP with variation of the factor.

The statistical relationship between the studied indicators studied using the correlation method indicates the feasibility of constructing the following regression model (equation):

$Y=a_{0}+a_{1} \times x_{1}$

where:

$\mathrm{a}_{0}-$ free term of the equation

$\mathrm{a}_{1}-$ net regression coefficient

Therefore, the formula dependence can be represented as follows:

$Y=12,15+0,23 \times x_{1}$

\section{Results}

During the study, confidence intervals are constructed that help to understand how much the obtained point estimate can deviate from the true value of the parameter. The obtained confidence intervals are presented in table 6.

Table 6. Forecast values of bank loans, billion tenge

\begin{tabular}{|l|l|l|l|l|}
\hline Year & Forecast & $\begin{array}{l}\text { Upper } \\
\text { interval }\end{array}$ & $\begin{array}{l}\text { Lower } \\
\text { Interval }\end{array}$ & $\begin{array}{l}\text { Parameter estimation } \\
\text { multiple regression }\end{array}$ \\
\hline
\end{tabular}

In general, the forecast values obtained on the basis of the solution of the multivariate regression equation are within the margin of error and can be taken into consideration for the formation of forecast indicators. The results of the study confirm the significance of the factor selected for analysis, which affects the change in GDP growth rates.

\section{Discussion}

The results of economic and mathematical modeling for assessing the influence of the factors we have chosen on the rate of economic growth are confirmed by the following theses (conclusions):

- the dependence of economic growth on the growth of innovation and its results in the form of high-tech products in the total volume of industrial exports was identified; 


\section{ENTREPRENEURSHIP AND SUSTAINABILITY ISSUES}

ISSN 2345-0282 (online) http://jssidoi.org/jesi/

2020 Volume 8 Number 1 (September)

http://doi.org/10.9770/jesi.2020.8.1(82)

- it was established that the influence of factors such as R\&D expenses and bank loans affect economic growth indirectly depending on external and internal economic and financial stability, the level of risks and the relevant regulatory practice in the country;

- it is proved that the influence of all factors on economic growth is equally blocked by the sharply negative effect of crisis phenomena, which reduces the effectiveness of any incentive measures in the field of enhancing investment and innovation in sectors at the crisis and post-crisis stages of the economic cycle;

- the asymmetry of state regulation measures was confirmed when, if financing and lending to innovations in the real sector are necessary to accelerate the pace of economic growth, bank loans are still not quite accessible for small businesses, despite the fact that an industrial-innovative development strategy is being implemented;

- in terms of lending to innovations of small businesses for Kazakhstan, the prospects for predominantly shortterm and medium-term loans (3-5 years) have been determined against the background of a deficit in budgetary constraints and a lack of own sources of investment financing, which is most important for the purchase of readymade innovative technologies and equipment in the context of catch-up development (Kalkabayeva, Kurmanalina, Gusmanova, 2017).

\section{Conclusion}

A critical rethinking of a number of scientific concepts in the context of modern conditions for the interaction of subjects of the financial and innovative sectors of the economy, which are distinguished by frequent cyclical fluctuations and exacerbation of contradictions in the interaction of sectors, predetermined the choice of the research methodology in favor of the theory of asymmetry of information and institutional-evolutionary theory of economic development. It was found that the dependence of economic growth rates can be traced, including on the results of the innovative component of the real sector, which, in turn, largely depends on the sufficiency of R\&D and expenditures on them or the availability of borrowed funds that financial and credit institutions can provide. The state, stability of sectors and the economy as a whole, as well as the priorities that the state sets for itself, as a rule, determine the nature, quality and orientation of the process of interaction between subjects of the financial and innovative sectors of the economy, depending on institutional changes in the structure of the economy. At the same time, the deepening of existing contradictions and problems in the interaction of entities of these sectors is due to the inconsistency (asymmetry) of macroeconomic effects, based on the different directions of target orientations of the subjects of interaction, unsatisfactory quality of information, polarity of behavioral strategies, the level of authenticity of regulatory measures, as well as distortion of expected results (effects) at the micro, meso and macro levels.

The fulfillment of a special role in the process of adjusting the institutional infrastructure to eliminate asymmetric macroeconomic effects, in our opinion, is intended to provide the state, which should pursue a balanced policy of preventive stimulation and regulation, taking into account the peculiarities of key stages of the economic cycle and the asymmetry in the interaction of subjects of key sectors of the economy. In particular, at the stage of crisis and recession, for Kazakhstan, a mechanism of comprehensive support of innovations can be used, which suggests that this stage is usually characterized by passivity of the financial sector entities, and, on the contrary, by the activity of subjects of the real (innovative) sector, when the latter search financial support for the implementation of their ideas in order to ensure the outcome of their crisis. The most acceptable option in this case is, on the one hand, the initiation of state programs to support the innovation sector, involving a system of incentive measures for banks, and on the other hand, the partial participation of financial and credit organizations, depending on the complexity of the stages of the innovation process (possibly together with state-owned banks of a specialized level) taking into account their resource capabilities and current regulatory standards. On the contrary, in a period of prosperity and economic growth, it is advisable to use a mechanism to stimulate the growth of innovation sector entities. This mechanism involves the creation of a network of specialized industry and innovation banks, in which the resource, personnel, methodological, technical and technological potential adequate to the needs of various sectors of the real sector is concentrated. The special status of these banks 


\section{ENTREPRENEURSHIP AND SUSTAINABILITY ISSUES}

ISSN 2345-0282 (online) http://jssidoi.org/jesi/ 2020 Volume 8 Number 1 (September)

http://doi.org/10.9770/jesi.2020.8.1(82)

implies the use of special regulatory measures in relation to them on the basis of the principle of budgeting, focused on the result: the provision of packaged incentive tools on the part of the state in the field of prudential standards, taxation, monetary policy, antitrust laws, etc. in strict dependence from the contribution of credit institutions to the development of the economy (increase in the share of loans in risky but priority sectors, participation in venture capital, development of flexible loan products focused on the development of innovative sector regions, etc.)

\section{References}

Nakipova, G., Akhmetova, K., Kamenova, M.Zh. 2013. Marketing - management in the complex socio-economic system: Basic ideas, aims, tasks. World Applied Sciences Journal, 27(6), 723-728.

Rakhmetova, A., Kalkabayeva, G., Iskakova, Z., Kurmanalina, A., Turmakhanbetova G. 2019. Institutional conditions of interaction of financial-credit and innovative economic sectors. Entrepreneurship and sustainability issues, 7(1), 716-730. https://doi.org/10.9770/jesi.2019.7.1(51)

Zavadska, D. 2018 Determining the role of banks in the financing of innovative development processes of the economy. Baltic journal of economic studies, 3(4), 68-73. https://doi.org/10.30525/2256-0742/2018-4-3-68-73

Dwenger, N., Fossen, F., Simmler, M. 2020. Firms' financial and real responses to credit supply shocks: Evidence from firm- bank relationships in Germany. Journal of Financial Intermediation, 11(41), 585-573. https://doi.org/10.1016/j.jfi.2018.01.003

Egyed, I., Pola, P. 2020. Industrial policy revival in France: new dilemmas, challenges and instruments. Teres Tarsadalom, 1(34), 96-118. https://doi.org/10.17649/TET.34.1.3158

Wu, L., Xu L. 2020. Venture capital certification of small and medium-sized enterprises towards banks: evidence from China. Accounting and Finance, 2(60), 1601-1633. https://doi.org/10.1111/acfi.12489

Shchenin, R. 2010. Banking systems of the countries of the world: a training manual. M.: KNORUS, 400 p.

Hombert, J., Matray, A. 2019. The Real Effects of Lending Relationships on Innovative Firms and Inventor Mobility. Review of Financial Studies, 7 (30), 2413-2445. http://hdl.handle.net/10.1093/rfs/hhw069

Shioji, E. 2019. Quantitative 'flooding' and bank lending: Evidence from 18 years of near zero interest rate. Journal of the Japanese and International Economies, 7(52), 107-120. https://doi.org/10.1016/j.jjie.2019.01.003

Polyakova, Yu. 2012. Authorities can force banks to finance innovation. M.: KNORUS, 212p.

Shmeleva, E. 2017. Many tasks of PPP are not feasible for commercial banks. Russian business newspaper, 2(831), 90-98.

Official site of RUSNANO. 2018. Kazyna Capital Management, VTB Capital and I2BF Holdings create the Russian-Kazakh venture fund for nanotechnology. http://www.rusnano.com/about/press-centre/news/75523

Finogenov, I. 2012. Eurasian integration is the achievement of the optimal structure of the region's economies based on the principles of sovereignty and equality. Money and credit, 2(15), 7-11.

The state program of industrial and innovative development of the Republic of Kazakhstan for the period 2015-2019. Ministry of Investment and Development of the Republic of Kazakhstan. http://www.mid.gov.kz

The strategy of innovative development of the Russian Federation for the period up to 2020. http://www.consultant.ru

Blauberg, I. 1969. Systematic approach: prerequisites, problems and difficulties. Moscow: Nauka, 48 p. 


\section{ENTREPRENEURSHIP AND SUSTAINABILITY ISSUES}

ISSN 2345-0282 (online) http://jssidoi.org/jesi/ 2020 Volume 8 Number 1 (September)

http://doi.org/10.9770/jesi.2020.8.1(82)

Veblen, T. 1984. Theory of the idle class. Moscow: Progress, 368 p.

Rozmainsky, I. 2017. The history of economic analysis in the West. Library: Second-hand bookshelf's shelf, Moscow: KNORUS, 313p.

Schumpeter, J. 1982. Theory of Economic Development. M.: Progress, 455p.

North, D. 1997. Institutions, institutional changes and the functioning of the economy. M.: Fund of the economic book Beginnings, 190p.

Coase, R. 1993. Firm, market, law. Moscow: Depot LTD, 395 p.

Kleiner, G. 2018. An enterprise in an unstable economic environment: risks, strategies, security. Moscow: Economics, 288 p.

Polterovich, V. 2016. Institutional traps - the result of an incorrect reform strategy. Economic Science of Russia, 1(9), $22-28$.

Beloglazova, G. 2011. The development strategy of the regional segment of the banking system. Banking, 2(11), $34-37$.

Tosunyan, G. 2018. Unresolved issues of long-term resource supply of credit organizations. Association of Russian Banks. 212 p.

Tselishchev, I. 2019. Japanese growth model: savings, lending, investment. World Economy and International Relations, 6 (18), 87 -96.

Avagyan, G. 2012. Regional Banking Cluster. Moscow: INFRA-M, 224 p.

Zverkova, T. 2018. Regional banks in a transformational economy: approaches to the formation of a development concept. SpB: Press Agency, 214 p.

Official site of the World Bank. http://www.worldbank.org

Kalkabayeva, G., Kurmanalina, A., Gusmanova, Zh. 2017. Current State and Forecasting of the Development of Bank Crediting in Kazakhstan. Journal of Advanced Research in Law and Economics, 4(26), 1161-1166. https://doi.org/10.14505/jarle.v8.4(26).13

\section{Acknowledgements}

The article was prepared based on the results of an intermediate stage of research "Development of a systematic regulation mechanism for financial and credit organizations to support the innovation sector in the context of sustainable

macroeconomic effects", carried out under grant funding of the Ministry of Education and Science of the Republic of Kazakhstan Grant Agreement Number 0118 PK01143 
Aibota RAKHMETOVA is Doctor of Economic Sciences, Professor of Karaganda Economic University of Kazpotrebsoyuz, Karaganda, Kazakhstan. Research interests: problems of macroeconomic regulation, the interaction of the banking and real sectors of the economy; financial support for the development of real innovations, development of the banking system, role of financial and credit organizations in ensuring economic growth

ORCID ID: orcid.org/0000-0002-0008-4887

Gaukhar KALKABAYEVA is Candidate of Economic Sciences, Associate Professor of Karaganda Economic University of Kazpotrebsoyuz, Karaganda, Kazakhstan. Research interests: bank lending, monetary policy; financial support for small and medium-sized businesses, sources of financing for the innovation sector

ORCID ID: orcid.org/0000-0002-5954-0787

Anar KURMANALINA is Candidate of Economic Sciences, Professor of Karaganda Economic University of Kazpotrebsoyuz, Karaganda, Kazakhstan. Research interests: housing financing, development of mortgage lending, investments, banking system problems

ORCID ID: orcid.org/0000-0002-0702-8634

Zhanar GUSMANOVA is Candidate of Economic Sciences, Professor of Karaganda Economic University of Kazpotrebsoyuz, Karaganda, Kazakhstan. Research interests: housing financing, development of mortgage lending, investments, banking system problems

ORCID ID: orcid.org/0000-0002-1872-0378

Gulzira SERIKOVA is Candidate of Economic Sciences, Professor of Karaganda Economic University of Kazpotrebsoyuz, Karaganda, Kazakhstan. Research interests: finance, insurance, banks.

ORCID ID: orcid.org/0000-0001-9013-7059

Baglan AIMURZINA is Doctor of Economic Sciences, Professor of Kazakh University of Economics, Finance and International Trade, Nur-Sultan, Kazakhstan. Research interests: finance, taxes, investments, budget, credit.

ORCID ID: orcid.org/0000-0003-2625-7989

Make your research more visible, join the Twitter account of ENTREPRENEURSHIP AND SUSTAINABILITY ISSUES:

@Entrepr69728810

Copyright (C) 2020 by author(s) and VsI Entrepreneurship and Sustainability Center

This work is licensed under the Creative Commons Attribution International License (CC BY).

http://creativecommons.org/licenses/by/4.0/

cC) (i) Open Access 